\section{Learning about}

Library Research

\section{Betsy Diamant-Cohen and Annette Goldsmith}

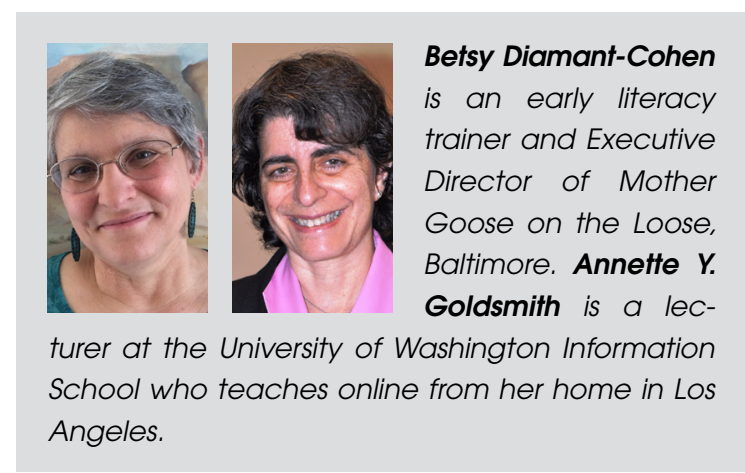

S ince this column seeks to highlight all aspects of research, in this issue we are going on a field trip to a place where researchers gather to share their findings, collaborate, learn, and celebrate-the most recent ALISE (Association for Library and Information Science Education) conference. According to its website, ALISE "is the global voice of library and information science education. ALISE leads innovative and highquality research, teaching, and service for educators and scholars in library and information science and cognate disciplines internationally through engagement, advocacy, and knowledge creation and dissemination." ALISE's membership consists mostly of library school professors and doctoral students and has a few practicing librarians with their doctorates. This column will share current research by LIS faculty and doctoral students relevant to children's librarians and showcased at the ALISE conference in Denver.

ALISE's annual conference traditionally takes place a few days before and in the same city as ALA Midwinter, enabling participants who sit on national committees to attend both conferences without breaking the bank, and this year was no different. Although it is relatively small, 322 attendees came from all over the world with representatives from Canada, China, Croatia (Hrvatska), Finland, Germany, India, Italy, Jamaica, South Korea, New Zealand, Oman, Peru, Puerto Rico, South Africa, Thailand, and the United States.

Many members also belong to ALSC, AASL, and/or YALSA (like the authors of this column) and within ALISE belong to SIGs (Special Interest Groups). The largest ALISE SIG is Youth Services. Each year, Youth Services SIG hosts a dinner in a local restaurant where members order and pay for themselves, enjoying the informal atmosphere while socializing and collaborating. Other SIGs relating to children's librarianship in some way include Historical Perspectives; Gender Issues; School Library Media; and Multicultural, Ethnic, and Humanistic Concerns.

Held on the first night of the conference, ALISE's "Works in Progress" poster session and reception enables attendees to discover current topics under investigation and to share knowledge on the topic with the researchers. Selected ALISE members display posters to highlight their research and share ideas; a booklet listing the title of each poster, the researcher(s) name(s), and the library school of each researcher is available. Conference attendees take a plate of scrumptious appetizers (and sometimes a glass of wine) and then walk around the room looking at posters and asking questions of the researchers.

This year's "Works in Progress" posters related to children's services included:

- "Young Children's Individual Interest \& Information Practices: Pilot Study Findings \& Lessons Learned." Sarah Barriage, Rutgers University.

- "Learning and Creation in Makerspaces: Implications for Expanding LIS Education." Kyungwon Koh, University of Oklahoma. 
- "Young People's Information Practices in Library Makerspaces.” Xiaofeng Li, Rutgers University.

- "Neighborhood Walks and Community Talks: A Research Study Examining Public Library Family Outreach Strategies and Challenges." J. Elizabeth Mills, University of Washington; Kathleen Campana, Kent State University; Michelle H. Martin, University of Washington.

- "The Challenge of Collaboration between Schools and Libraries." Anu Ojaranta, Abo Akedmi University, Finland; Siinmari Tikkinen, Oulu University, Finland.

- "A Continuum of Care: School Librarian Interventions for New Teachers." Rita R. Soulen, Old Dominion University.

- "Towards a Taxonomy of School Libraries." Presenting Author: Stephanie Sukoff Trzeciakiewicz, Old Dominion University; Gail Dickinson, Old Dominion University.

During the daytime, conference attendees share their research. Presentations come in many different forms: panels, lightning talks in which each person gets just a few minutes to present, individual papers, SIG programs, and a President's Program. All submissions for the conference (including posters) must pass the peer-review process in order to be accepted.

This year's conference theme was "The Expanding LIS Universe." Several sessions focused on media literacy-how LIS can educate people to spot and respond to fake news. In "Don't Get Faked Out by the News: Becoming an Informed Citizen," Dr. Lesley Farmer from University of CaliforniaLong Beach talked about the phenomenon of fake news sparking interest in media literacy. She encouraged students to use reputable sources and fact-checking sites, such as https:// mediabiasfactcheck.com/2016/07/20/the-10-best-fact-check ing-sites/. She also directed conference participants to check out her website at http://tinyurl.comFakeNewsLibGuide.

Within the framework of teaching courses in library and information studies, other topics included social justice, computational thinking, curriculum design and development, research methods, education trends, data analytics, data science, open access, multiple literacies, mobile technology, STEM in libraries, history of librarianship, international education, community outreach, user experiences, race and gender issues, translated international children's books, connected learning, transmedia storytelling, information ethics, diversity and inclusion, health literacy, reference, foundational and specialized content, grants, online education, information literacy, continuing education, archives/ preservation, professionalism, leadership, faculty of color, accreditation, motivation for enrolling in doctoral education, and serving people with autism. Sessions we attended focused on innovative pedagogies for teaching, action-based research, educating creative minds, and teaching Javascript as social justice.
Unlike typical conferences, academic publishers display their wares on exhibit tables near the registration desk. Since many conference attendees have written or co-written textbooks and reference guides, a list of the attendees is sent to the publishers ahead of time. Responsible publishers check if any of their authors will be attending the conference, and if so, they bring at least one book per author.

ALISE members are eligible for a number of awards that promote and celebrate scholarship and service to the organization. There are awards for scholarly papers, excellence in teaching, leadership, service to ALISE, research excellence in young adult services, school library connections, best doctoral posters, and a few travel awards enabling doctoral students to come to the conference. A full list of the awards and their descriptions can be found at http://www.alise.org/ awards-grants.

The ALISE conference is also a great place for networking. During the "Birds of a Feather" session, Youth Services SIG members introduce themselves and give a brief recap of the project(s) they are working on. After learning about one another's research in this friendly, collegial atmosphere, colleagues often find ways to collaborate. For instance, our SIG members might be invited to guest lecture in one another's classes after the conference. Some people go to the ALISE hospitality suite, hang out for an hour or so, eat hors d'oeuvres, and get introduced to one another. In fact, that is how the authors of this column met ten years ago and became fast friends.

Later in the conference, another evening reception/poster session is held. Doctoral students stand beside their posters and describe their dissertation research. This year, only a few posters were relevant for children's librarianship:

- "The Multimodal Power of Storytime: Exploring an Information Environment for Young Children." Kathleen Campana, University of Washington.

- "Young Children's Individual Interests \& Information Practices: Pilot Study Findings \& Lessons Learned." Sarah Barriage, Rutgers University.

- "Modeling Participatory Literacy: An Analysis of Social Reading and New Media Convergence in Vlogbrother's Videos, 2007-2012." Alaine Martaus, University of Illinois, Urbana-Champaign.

- "Safe for Whom?: Censorship and Safety on the Reality Storytelling Stage." Sarah Beth Nelson, University of North Carolina.

- "Censorship in Public Libraries: An Analysis Using Gatekeeping Theory." Elaine Steele, University of Alabama. \& 